\title{
Consumers’ Perceptions of Green Marketing in the Hotel Industry
}

\author{
S. Punitha ${ }^{1}$, Yuhanis Abdul Aziz ${ }^{1}$ \& Azmawani Abd Rahman ${ }^{2}$ \\ ${ }^{1}$ Department of Management and Marketing, Faculty of Economics and Management, Universiti Putra Malaysia, \\ Selangor, Malaysia \\ ${ }^{2}$ Halal Product Research Institute / Faculty of Economics and Management, Universiti Putra Malaysia, Selangor, \\ Malaysia \\ Correspondence: Yuhanis Abdul Aziz, Department of Management and Marketing, Faculty of Economics and \\ Management, Universiti Putra Malaysia, 43400 Serdang, Selangor Darul Ehsan, Malaysia. Tel: 603-8946-7674. \\ E-mail: yuhanis@upm.edu.my
}

Received: November 19, 2014 Accepted: July 7, 2015 Online Published: December 21, 2015

doi:10.5539/ass.v12n1p1

URL: http://dx.doi.org/10.5539/ass.v12n1p1

\begin{abstract}
This paper attempts to explore the evolution of green marketing in the hotel industry. This study is guided by three research questions: (1) to explore the level of understanding of local and international tourists on green marketing; (2) to gather tourists' points of view if marketers have failed or they have never really tried to adopt the concept; and (3) to examine the level of awareness of tourists relating to green practices embraced by hotels. Purposive sampling using the Maximum Variation Sampling (MVS) technique is used to capture a wide range of perspectives in selecting the respondents. The discussion reveals that the concept has evolved hastily in developed countries while it is an emerging trend in developing countries like Malaysia. While some hotels have already begun to respond to environmental concerns in the country, the lack of promotions and advertisements have become part of the causes of knowledge non-appearance. This paper further concludes that green marketing concept should not just be adopted as a marketing tactic, but has to be considered with much greater dynamism, as it has ecological and social elements within it.
\end{abstract}

Keywords: environment, green marketing, hotel industry, Malaysia, sustainable development

\section{Introduction}

Sustainability is no longer an emerging business megatrend but has become a dominant movement that stands to revolutionize the way the world does business today. In a business context, sustainability does not only involve the adoption of green practices but also about how marketing meets the needs of its people in the midst of sustainable development. While this remains challenging for marketers, many companies have adopted the concept of green marketing as an integral part of their business strategies. At this point, green marketing is seen as a philosophy which largely advocates sustainable development. However, when topics such as green marketing and sustainable development are discussed, the product-based industry which involves manufacturing (e.g., consumer goods and household products) is given greater attention and concern (Punitha \& Rasdi, 2013). The reason behind this is because the usage of raw materials and the effects of waste produced in relation to the environment are more obvious compared to the service-based industry. Moreover, services by their very nature are physically intangible (Berry, 1980; Zeithaml, Parasuraman, \& Berry, 1985) and may not be visible to the naked eye. According to Shieh (2012, p. 536), the service industry is known as "the silent destroyer of the environment."

Looking at the major service sector, the tourism industry in Malaysia has been experiencing a resilient phase of development while becoming the country's major source of income and a catalyst to the Malaysian economic renaissance. It is expected to grow continuously in the coming years due to the rising promotional activities undertaken by the government and also the increasing status of the country as a potential tourist destination. On the other hand, this development often corresponds with unsustainable consumption practices thereby jeopardising the environments and natural riches. Since the hotel industry is at the heart of the tourism industry, the need to "Go Green" is essential for both service sectors. Also, due to the rising need to fulfil one's corporate social responsibilitiy (CSR), hoteliers are using this concept in operating their businesses (Shafaat \& Sultan, 2012). In the past two decades, the global hotel industry has basically increased its involvement with the 
environment (Fernández-Alles \& Cuadrado-Marqués, 2012). The adoption of green practices and technologies in the operation are major parts of the hotels' involvement and it is growing gradually with the need to gain a competitive advantage over the other lodging services. This provides a trend among all hoteliers to necessitate their service delivery with the green marketing concept.

While these efforts are being embraced, the level of understanding among consumers towards this green marketing concept is still questionable. On the whole, Joel Makower, who writes on green marketing (as cited in Shafaat \& Sultan, 2012, p. 184) states that one of the challenges that green marketing encounters is "lack of standards or public consensus about what constitutes green.” Correspondingly, Myung, McClaren and Li (2012) also mention that the green marketing concept within the hotel industry is still at its infancy phase and more developments of literature and theoretical supports are necessary. Other than that, a more rigorous level of understanding among local and international tourists seems important to better comprehend the evolution of green marketing within the industry. This is because both local and international tourists have been contributing significantly to the development of the hotel industry in Malaysia. Despite the industry's strong historical growth of local tourist appearance, Malaysia's ecological attractiveness has contributed to the substantial growth in international visitors received every year. Due to the different acceptance and exposure level of the green marketing concept in different countries, the tourists will probably have different perspectives and these may affect their readiness to go environmentally friendly when they travel. Thus, it is vital to include both groups when studying the hotel industry.

At the same time, the need to go environmentally friendly has encouraged many organisations to maximise the potential benefits by embracing the green elements in their internal operations. However, when this is given back to the society, the level of awareness or understanding of these practices by consumers is doubtful. Therefore, this qualitative study intends to perfect the pitch by ensuring that society understands and realises what is given out to them by the service providers, such as hoteliers. To address the research problem mentioned above, three research questions have been identified and they are as follow: (RQ1) To what extent do the local and international tourists understand what green marketing is? (RQ2) From the tourists' points of view, have marketers failed in adopting the concept of green marketing or have marketers never really tried to adopt the concept of green marketing? (RQ3) Are tourists really aware of the green practices embraced by the hotel industry? Based on the research questions, the research objectives are: (1) to explore the level of understanding of local and international tourists on green marketing; (2) to gather tourists' points of view if marketers have failed or they have never really tried to adopt the concept; and (3) to examine the level of awareness of tourists relating to green practices embraced by hotels.

This research is of significance to the domain of sustainable development as it extends the knowledge on green marketing that currently exists in the field. Knowledge about public understanding towards this concept can be used as a guide by marketers who are aiming at the green market. Applying the known appeals into their promotional activities or advertisements could further strengthen their tactics to outfit the green segments. While Malaysia is experiencing a tremendous pace of tourism development with an increase in tourist arrivals every year, catering to these international tourists' needs would further develop the tourism and hotel sector. Besides that, academicians and researchers who have high interest in conducting a research on consumers and their buying behaviour of environmentally friendly products or services could also gain benefits through a replication of this study in a different context or industry that they are fascinated in. Lastly, this study also makes contribution to serve as a support to the efforts the Malaysian government has put into realising the green concept in the country. Recently, the government was totally involved in many green ventures such as green technology, green business promotions, intensive programs and motivating the public to go environmentally friendly (Aman, Harun, \& Hussein, 2012) in order to build a green economy (The News, 2011).

\section{Literature Review}

In recent years, understanding the relationship between businesses and the natural environment has become a matter of interest for economists, sociologists and environmentalists. In actual fact, environmental concerns have been incorporated into the research agendas of marketing and management scholars since the late 1960s (Leonidou \& Leonidou, 2011). Numerous terms have been proposed in order to comprehend this relationship, such as green marketing (Leonidou, Katsikeas, \& Morgan, 2013; Chen \& Cheng, 2012; Chen, 2010; Hartmann, Ibanez, \& Sainz, 2005; Ginsberg \& Bloom, 2004; Peattie, 2001; Smith, 1998; Ottman, 1993), sustainable marketing (Fuller, 1999; van Dam \& Apeldoorn, 1996), ecological marketing (Henion \& Kinnear, 1976; Fisk, 1974), greener marketing (Charter \& Polonsky, 1999; Charter, 1992), environmental marketing (Peattie, 1995; Coddington, 1992, 1993) and enviropreneurial marketing (Menon \& Menon, 1997). According to Chamorro, Rubio and Miranda (2009), these terms are principally identical regardless of how they are distinguished 
conceptually. Harmonising the development of the business with the natural environment is the key, whereas improving human well-being by lessening the damage to the Earth and its organisms are the objectives of these terms. In that sense, the term "green marketing" has become rather common and used extensively within the practice of marketing (Jay, 1995).

The passing of time has also brought a sense of evolution to the overall green marketing concept. Peattie (2001) clearly points out that green marketing can be divided into three phases. The first phase is known as "Ecological" green marketing where all the marketing programmes and activities are implemented to minimize the damage to the environment and to offer the best possible solutions to prevent environmental problems. The second phase is named as "Environmental" green marketing wherein more attention is paid to clean technology that includes the designing of new products to solve waste and pollution issues. The third phase is "Sustainable" green marketing which came into prominence in the late 1990s and early 2000. This seemed to be a more radical approach which involves the entire environmental costs of production and consumption to produce a sustainable economy.

While the concept is categorized into different phases, they are believed to share narrower meanings. Pride and Ferrell (1993, p. 8) define green marketing as an organisation's efforts in designing, promoting, pricing and distributing products that will not harm the environment. Likewise, Ginsberg and Bloom (2004) add to it as an application of marketing concepts and elements to encourage exchanges that satisfy organisational and individual goals in a way that will preserve, protect and conserve the physical environment. These marketing concepts are formed as creative approaches to develop a product or service needed by a group of consumers by communicating effectively using the right pricing and distribution method. Overall, green marketing looks into issues that affect the fundamentals of people's quality of life (Peattie, 1995).

On the other hand, green marketing has been used as one of the strategies for achieving sustainable development. According to the World Commission on Environmental Development (1978, p. 1), sustainable development is defined as "meeting the needs of the present without compromising the ability of the future generations to meet their own needs." Sustainable development also leads to the integration of economic, social and environmental dimensions in decision making without sacrificing the needs of future generations. This is what the outcome of green marketing is; diminishing environmental impacts for a more secured future. The development of energy-efficient operations or renewable energy, water-saving equipment, pollution control mechanisms, biodegradable and recyclable materials, and environmentally friendly products are all part of green marketing which is to achieve sustainable development.

Table 1. Winners of ASEAN Green Hotel Awards 2014 - Malaysia

\begin{tabular}{ll}
\hline Location & Hotel's name \\
\hline Sabah & Shangri-la Tanjung Aru Resort and Spa Kota Kinabalu \\
& Nexus Resort Karambunai \\
& Shangri-la Rasa Ria Resort Tuaran \\
\hline Sarawak & Riverside Majestic Hotel Kuching \\
& Miri Marriot Resort and Spa \\
\hline Kuala Lumpur & Mandarin Oriental \\
& Shangri-la Hotel \\
& Renaissance Hotel \\
\hline Kedah & The Andaman Langkawi \\
\hline Penang & Shangri-la Rasa Sayang Resort and Spa \\
\hline
\end{tabular}

(Source: Malay Mail Online, 2014)

In specific, hotels have also adopted various green marketing strategies to respond to the emerging environmental issues. Chan (2008) calls these strategies as environmental management systems (EMSs) which include strategies such as efficient use of energy, water and material resources in all aspects of the hotels' operations. To recognise the efforts that hotels are making to successfully implement their green marketing strategies, various awards and certifications are given. This is a form of appreciation for their contibutions and also serves as motivation for the others to progress towards such green commitments. For instance, 86 hotels across the Asean region were honoured with the Asean Green Hotel Recognition Award in 2014 (Veno, 2014). Ten hotels from Malaysia were among the 86 hotels to receive this prestigious award and the list of hotels is 
provided in Table 1 . The objective of this award is to recognise hotels that have gone beyond conventional practices and have embarked on green and environment friendly measures in support of responsible tourism (World Luxury Tourism, 2014). In order to be nominated for the award, the hotels need to adhere to the criteria and requirements enshrined in the Asean Green Hotel Standard. Further illustrations of these criteria and requirements are outlined in Table 2.

Table 2. Criteria and Requirements of Asean Green Hotel Standard

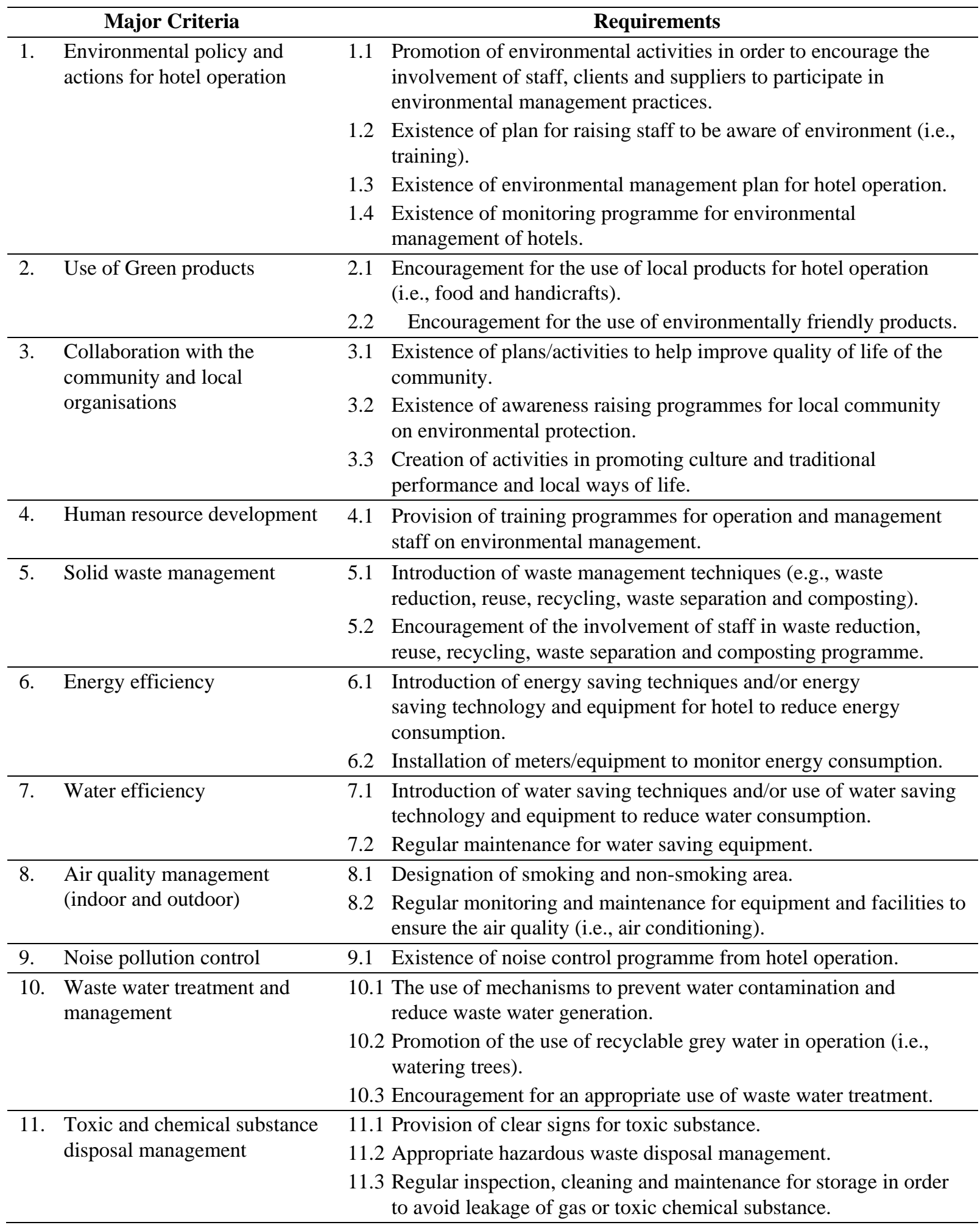

(Source: Ministry of Tourism and Creative Economy, 2012) 
For the certifications awarded to hotels, there are over 800 different green certifications offered around the world (Green Hotels Association, n. d.). These certifications provide numerous benefits to the hoteliers where they serve as important green marketing tools, relieve the hotel of the burden of proof, help in tracking and bench-marking performance, and provide an advantage to the hoteliers to advertise as green hotels. On the other hand, there is no "one size fits all" when it comes to green certifications as each certification audit has its own standard which sometimes offers more legitimate measures of eco-consciousness than others. Overall, hotels believe the certifications will not only help potential customers to make better informed choices but also serve as claims that the hotels in question are environmentally friendly and have adopted sustainable approaches that reduce environmental damages.

Despite all these lines of evidences supporting the green revolution in the hotel industry, there is not enough empirical data to show if the customers are really aware and understand what the hoteliers have in store for them. There is also no evidence to support if the hotels have successfully created an emotional connection between their customers and their green marketing strategies. This situation remains unexplained and this study intends to explore and gain insights into the best potential answers to the situation.

\section{Methodology}

This study employs a qualitative approach in order to explore the level of understanding of the respondents regarding the green marketing concept. Maximum Variation Sampling (MVS), which is a form of purposive sampling technique, is used in this study to obtain a variety of perspectives while selecting the respondents. According to Creswell (2012), this technique allows researchers to select respondents that are likely to be knowledgeable. Besides that, Neuman and Kreuger (2003) mention that this technique is suitable for specific investigations on a specific group of people particularly when a researcher requires an in-depth exploration. At the same time, MVS technique also has the ability to provide rich insights into a phenomenon by looking at it from all angles. This method also further helps the researcher to find common patterns or themes that emerge in responses dealing with the particular phenomenon. Despite the commonalities, differences may also be recognised (Ary, Jacobs, Razavieh, \& Sorenson, 2009). List (2004) also states that this MVS technique is frequently used when the size of the sample is small.

In relation to this, five local tourists and five international tourists were chosen ranging from various demographic profiles which were viewed as typical in nature. Table 3 describes the respondent's demographic profile in detail. The local tourists were from Malaysia and they were chosen based on varied cultural orientations, such as race, to enable a collection of rich responses in answering the research questions. The international tourists were chosen from different world continents in which two were Asians, two from North America and another one from Australia.

Table 3. Demographic profile of respondents

\begin{tabular}{|c|c|c|c|c|c|c|}
\hline $\begin{array}{l}\text { Assigned } \\
\text { Number }\end{array}$ & Country & Age & Gender & Race & $\begin{array}{c}\text { Marital } \\
\text { Status }\end{array}$ & Occupation \\
\hline $\mathrm{R} 1$ & Malaysia & 29 & Male & Malay & Married & School teacher \\
\hline R2 & Malaysia & 34 & Female & Indian & Married & Bank officer \\
\hline R3 & Malaysia & 32 & Female & Malay & Married & Manager \\
\hline R4 & Malaysia & 42 & Male & Indian & Married & Businessman \\
\hline R5 & Malaysia & 55 & Male & Chinese & Married & $\begin{array}{l}\text { Businessman } \\
\text { (Restaurateur) }\end{array}$ \\
\hline R6 & Singapore & 32 & Male & - & Married & Businessman \\
\hline R7 & China & 35 & Male & - & Married & Businessman \\
\hline R8 & U.S. & 42 & Female & - & Married & Housewife \\
\hline R9 & U.S. & 44 & Male & - & Married & Software engineer \\
\hline R10 & Australia & 42 & Male & - & Married & $\begin{array}{l}\text { Quality control manager } \\
\text { (Assembly) }\end{array}$ \\
\hline
\end{tabular}


According to Marshall, Cardon, Poddar and Fontenot (2013), no studies have cited qualitative methodologists for an appropriate sample size. It is therefore ultimately a matter of judgment or experience based (Sandelowski, 1995) and as long as the sample size has all the potential to adequately answer the research questions (Marshall, 1996). For simple questions or very detailed studies, this might be in single figures (Sandelowski, 1995) in which studies with smaller samples will allow a fuller exploration of a broader range of respondents' experiences (Russell \& Gregory 2003). In practice, the accurate sample size also becomes obvious when data saturation is achieved (i.e., new categories, themes or explanation stop emerging from the interviews) as the study progresses (Sandelowski, 1995). By considering these aspects, a conscious selection of a small sample size (10 respondents) seemed appropriate for this study to secure information relevant to the research questions.

Basically, the respondents were not reluctant to be interviewed or to express their opinions regarding the research problem. These respondents were obtained from Sunway Lagoon Theme Park, one of the top tourist spots in Malaysia that attracts tourists from all over the world. A semi-structured interview was conducted with each respondent as this method offers a greater degree of flexibility in structure that allows the interviewer to clarify questions or answers, offers prompts, probes responses and elicits new ideas. Fraenkel and Wallen (2003) also mention that flexibility is important as it allows a researcher to approach and uncover unexpected areas of exploration. In addition, Mitchell and Jolley (2004) support by stating that such flexibility is essential for an exploratory study as the researcher has not identified all the key variables before the interviews. In the appendix, the interview questions for this study are attached.

Regarding the location of the interview, a more natural setting was employed. The resting areas along the way to the theme park were found to be comfortable and free of distractions. The overall idea is to interview the respondents while they are utilizing the accommodation service as a tourist because questioning them in their surroundings can bring needed details about their behaviours to light. According to Adams and Cox (2008), the setting of the interview can affect the success of the interview session as respondents are more likely to provide positive feedback in a natural setting. In addition, there were no experimental and control groups. On average, each interview session took about 30 minutes and it was ended when no new materials or new codes were generated.

The interviews were recorded digitally and in general, this is a preferred method in exploratory studies as it allows the researcher to concentrate fully on the discussion rather than trying to balance conversation and note-taking. Each respondent's permission was obtained prior to the recordings. The issues of confidentiality and anonymity were also addressed at the beginning of each interview and the respondents were assured that there would be no records of the interview with their names on. The respondents were also informed that they would only be required to discuss issues with which they felt comfortable.

A simple direct approach was employed when asking questions to the respondents to minimise confusion. The researchers themselves carried out the interviews and the sessions started with a series of preliminary questions such as country of origin, age, race (only for local tourists), marital status and occupation. Then, questions related to overall understanding of green marketing were asked. This was followed by narrowly defined questions related to the concept and also the hotel industry.

\section{Data Analysis}

The transcribed interview data was analysed using the inductive approach. In general, this approach is a common practice in qualitative research which involves searching through data to find any recurrent patterns. For this study, three sections pertaining to the research questions were identified. The first was "level of understanding", the second was "marketers have failed/never tried" and the last was "awareness of green practices." The data was then examined closely, line-by-line, to facilitate the categorisation process. The texts were written down in relevant sections and additional information or comments were written down separately in a different column to make sure no points were left out. During the grouping of data, common themes and patterns were identified. Then, each theme was examined separately and the relations between the themes were also studied. Lastly, the data was reported together with a few quotations from the original transcript to help communicate its meaning.

\section{Findings and Discussion}

The research findings reveal both local and international tourists have different perspectives towards green marketing. Referring to Table 3, the respondents were assigned numbers (R1 until R10) for anonymity purpose. Throughout the discussion, they were referred accordingly by using their given numbers. The term tourists was often used interchangeably with other terms such as customers and consumers in the discussion of this study as tourists are customers of the hotels and consumers of the hotels' services. The following findings and discussion are divided into 3 sections according to the research objectives of this study. 


\subsection{Level of Understanding on Green Marketing by Local and International Tourists}

When the local respondents were asked about their level of understanding, R1, R2, R3 and R4 claimed that green marketing merely referred to advertisement or promotion of goods that were environmentally friendly. They believed that terms such as "recyclable", "biodegradable", "eco-friendly" and "organic" were very much related to green marketing. According to them, Malaysians were getting themselves involved seriously with the recycling campaigns which had been carried out extensively in the country. They also stated that the government had given much support and encouragement for recycling while the community's participation level was improving gradually. As R1 is a school teacher, he further shared his experience by explaining that the households and children in the school had been widely exposed and taught on the possible benefits of recycling while practical knowledge and positive experiences had been generated in the process of supporting the recycling campaigns. R2 added that one of the major reasons for starting these recycling campaigns was due to the increasing pollution rate in the country.

While the four local respondents, namely R1, R2, R3 and R4, showed a larger degree of involvement towards the topic, R5 showed no interest in return. Well ahead, R5 explained the term "green marketing" by interpreting the phrase itself. He interpreted "green" as environment while "marketing" as a strategy used by companies to sell their products to the market. R5 also mentioned that the "No Plastic Bags on Saturdays" campaign probably could be an example of green marketing. When asked what the campaign was all about, he explained that it was a simultaneous nationwide campaign that the government had implemented for all hypermarkets and supermarkets in the country to no longer provide free plastic bags on Saturdays. He further added that shoppers were required to pay an additional amount of RM 0.20 for each plastic bag that they requested. When further asked if he supported the campaign, he replied that he would not request for a plastic bag if the items that he had bought could be carried without one. Overall, it is observed that he showed lack of interest in the topic discussed. By knowing that small qualitative studies are not generalizable in the traditional sense, this could actually become a matter of serious concern to understand if age is a contributing factor that results in a lack of interest and concern regarding environmental behaviour.

Looking at the international tourists, R6, R7, R8 and R9 equated green marketing to "environmentally sound" products. Their main explanations were just the same as the locals' perceptions. However, they gave more descriptions about the term. They believed that the objective of green marketing was to achieve minimal detrimental impact on the environment. They also mentioned, many businesses were using this to face limited natural resources and as a way to perform CSR. R8 added that companies were embracing it to reduce legal consequences. She added that the government of her country tried to protect the consumers and society by reducing the production of hazardous materials and compelling companies to offer accurate information about the environmental aspects of their activities. While in China, R7 mentioned that it was a growing trend for companies to include green elements in their operations. Compared to other international tourists, R10 gave a detailed explanation of what green marketing could be referred to. He mentioned that the term was extensively used by many companies that often claimed to be "green." To him, the concept of green marketing was wide and could be referred to consumer goods, industrial goods and also services. Generally, green marketing consists of a wide range of activities, including variations in products, packaging modification, improvement in the manufacturing and distribution processes, and changes in promotional efforts. The information gathered from this respondent seems to be very useful for this study as he had a broad range of experiences in the area of production. Looking from a housewife's point of view, when R8 was asked an additional question on how she viewed this concept, she mentioned:

"Whenever people talk about protecting the environment, many people will say that industrial pollution is one of the biggest issues besides carbon emissions by vehicles. In fact, families also play an important role in environmental protection and homemakers (meant as housewives) play a very important role in the process and can contribute a lot to the surroundings. Particularly, I'm very concern about the water and electricity usage at home and I always separate the trash for recycling purposes."

\subsection{Tourists' Points of View if Marketers Have Failed or They Have Never Really Tried to Adopt the Concept}

All the local respondents perceived that the government as a stakeholder by itself played a vigorous part in the protection of the environment. The government is seen to be committed to wide-ranging objectives for management and preservation of the ecosystem for sustainable development. Through campaigns and programmes, the government is striving hard to secure the environmental sustainability by educating the public to be socially responsible. Pressures from the government to comply with the environmental practices have also made businesses to practice green marketing. Overall, the local respondents see the government as a marketer 
who is responsible in innovating and educating the public for the need to go "green." They claimed that even though the efforts that the government had put in were not fully successful, they agreed that attempts had been taken and the public had been educated slowly. These findings can be supported by the study done by Omran, Mahmood, Aziz, and Robinson (2009) who mention that the government is spending more money for publicity and educating the public regarding environmental issues. In addition, in year 2010, the government launched a RM1.5 billion (GBP 300 million) soft loan scheme called Green Technology Financing Scheme (GTFS) to boost the involvement of corporations and entrepreneurs into green technology (KeTTHA, 2011). For instance, R3 mentioned:

"Due to the threat of global warming and increase in the pollution rate, the Malaysian Government is focusing more on green developments in recent years and making concerted efforts to encourage Malaysians to support environmentally friendly activities in the country. Additionally, efforts of the government in promoting green technology have been excellent."

When asked about the views on private and public organisations, R1, R2, R3 and R4 pointed out that they had seen advertisements relating to the "go green" concept and many companies in Malaysia were encouraging the public to "save the environment." They also clarified that the use of eco-label which highlighted the environmental benefits and effectiveness of the product had also increased in the country. However, they believed that probably it was just one of their strategies to reach and persuade customers to buy their products or to use their services. They added that, even though the public seemed to be apathetic, the concern towards sustainability was growing gradually. R2 also added:

"It is comforting to see consumers are purchasing green products more than ever, but that eco-friendly status remains doubtful."

Besides that, R5 mentioned that preventing damage to the environment had become a way of doing business for many people across the nation and many companies in the country had changed their ways towards a more sustainable and eco-friendly business practice. The responses given by the local respondents indicate that many organisations in the country have begun to realise that the green phenomenon is a serious marketing trend and incorporating the new concept into the business practices is an added advantage. In addition, the eco-friendly status remains to be a crucial factor in encouraging customers to make the right choice for circumstances that require them to consider the environmental aspects.

On the other hand, R7 mentioned that there had been a lot of major press coverage about the environmental issues in China, but yet, there had not been any actual or serious penetration across the region. With the continuing rise in the pollution rate and environmental awareness in the country, companies are in the process of recognising the need to go green. Thus, it is believed that it is an emerging trend in the country while R7 stressed that the view "marketers have failed or they have never really tried to adopt the concept" was inaccurate in the country's context. The other four respondents who were from the United States, Singapore and Australia pointed out that this concept emerged very long ago and had been advertised extensively in their countries. They believed that many companies in their countries were successful and dynamic in encouraging the public to use their green products and services. This indicates that country like China has been intensifying its effort to promote green growth in the country. Even though the process of embedding the green considerations into their core operations is not noticeable to some extent by its people, it is believed that the concept has received growing recognition from businesses around the country. In other words, the concept has actually gained attention to a large extent, prominently in the United States, Singapore and Australia.

At the same time, additional information was obtained as the respondents answered this research question. The respondents argued that the green claims were easy to make but difficult to verify thus leaving people misinformed and sometimes misled about the ecological attributes ascribed to many products. This is consistent with the research done by Bhaskaran, Polonsky, Cary and Fernandez (2006) who mention that the demand for eco-friendly goods such as food products has been slow to take-off because consumers tend not to believe the green claims made by organisations. As remarked by R9, this leaves the best serving products and services at their own challenging path to compete with the poor ones. R9 gave additional information by saying that the U.S. Environmental Protection Agency (EPA) encouraged organisations to use Environmental Management Systems (EMS) to help meet both regulatory requirements and voluntary stewardship goals in the areas of product design, energy efficiency and other sustainable practices. This information is somewhat similar to the view shared by R2. In common, consumers are becoming more sceptical about the green claims made by companies. Obviously, this is a threat to environmental responsibility and the track of making credible green marketing claims is full of challenges for marketers. 


\subsection{Awareness Related to Green Practices by the Hotel Industry}

R1 and R3 mentioned that it has always been an argument to indicate how hotels could implement green practices in their operations as they lacked tangibility. This statement is highly consistent with Berry (1980) and Zeithaml et al. (1985) who claim that service organisations lack physical presence. R2 and R3 said that the green practices of hotel industry were not apparent compared to product-based industry. When they were asked the meaning of apparent, they explained that the hotels might not be able to provide evidence to show to what extents their services were environmentally friendly. The respondents also indicated that they were more aware about the usage of refillable amenity dispensers (soap and shampoo), options to reuse the linens and towels, and availability of recycling bins in rooms. As R4 has travelled to many countries, he said that hotels provided options such as in-room options for guest to conserve water and energy. In addition, he said that these green initiatives were being practiced widely by luxury hotels instead of low-ranked hotels in both local and international grounds. When R5 was asked about the green practices embraced by hoteliers, he gave some different thoughts compared to others. He claimed that he had seen some signs and notifications in hotels about saving energy and water but he always disregarded them. When he was asked if those signs and notifications were found to be not attractive or interesting enough for him to commit towards environmentally friendly behaviour, he said:

"It's not about the hotel's ads or posters. But basically, I'm not really into environmental protection. I just do what I like. When it comes to hotel, I only ensure that I get a good and quality service."

When asked how he perceived "quality" in a hotel setting and if those green measures (e.g., energy and water saving, refillable amenity dispenser and options to reuse the linens and towels) affected the quality of services that he received, he mentioned:

"To me, it's all about how well a hotel conforms to the guest's expectations. At the same time, the guest must be willing to pay more for the extraordinary services, experience and feeling offered by the hotels. About these practices, I don't think they affect the quality because the guests are always given the choices to choose and decide what they want. But when it comes to refillable amenity dispensers, I believe it's a good strategy to reduce wastage because soap bars are always thrown away after being used once or twice, including bottles which are still partly full."

This gives a little insight into how baby boomers perceive quality as an important variable and this strong conviction is a driving force on how they purchase and consume. Indeed, there is also a prevailing attitude among boomers on the need to reduce the amount of waste produced and cultivate a better consumption habit and it is truly obvious that they have such intentions to do so.

When the international tourists were asked some questions relating to this research question, they managed to give some comprehensive responses. R6, R8 and R9 said that there were many green elements that could be adopted by a hotel. A hotel could be surrounded by natural verdant greenery. That would allow guests to enjoy the dramatic nature of the surrounding scenery. R6 further added that he visited Malaysia very often as the country is surrounded by lush tropical rainforests and blessed with exotic wildlife. He also believed that many tourists prefer Malaysia as a way to escape from the heat of plains in their countries. R6 also mentioned:

"Whenever I go for vacation with my family, I will choose hotels with such facilities. I prefer a room that comes with garden view, lake view or surrounded by tropical greenery. I think it's an advantage for Malaysian hotels as most of them are capable to include this in their offerings."

R7 further stressed that hotels in China had put high emphasis on energy saving technologies. According to him, the Chinese government had been encouraging hotels to include energy-efficient technologies as China is one of the largest energy consumers. Further, R10 claimed that hotels had been adopting green elements in many ways. For example, hotels used renewable energy sources such as wind, solar and geothermal power if necessary. While hotels obtain resources from their suppliers, the supply chain is also monitored frequently to ensure if the suppliers are capable in supplying green products and could effectively communicate environmental priorities. At the same time, the durable goods that are purchased are also checked if their quality allows for reusing, refinishing and upholstering. This clearly reveals that the international respondents are aware of the green practices embraced by hotels and are also able to recognise and further illustrate them. Table 4 provides the key findings of this study and summarises the entire discussion. 
Table 4. Summary of findings

\begin{tabular}{|c|c|c|}
\hline \multicolumn{2}{|c|}{ Respondents } & Keywords \\
\hline \multicolumn{3}{|c|}{ Level of understanding on green marketing by local and international tourists. } \\
\hline \multirow{4}{*}{ Local } & R1, R2, R3, R4 & $\begin{array}{ll}\text { - } & \text { Environmentally friendly } \\
\text { - } & \text { Recycling campaigns } \\
\text { - } & \text { Governmental sunnort }\end{array}$ \\
\hline & R1 & - Governmental support \\
\hline & & - Households \& kids - recycling benefits \\
\hline & R2 & - Pollution rate \\
\hline \multirow{6}{*}{ International } & R5 & $\begin{array}{l}\text { - A strategy used by companies } \\
\text { - } \quad \text { "No plastic bags on Saturdays" campaign }\end{array}$ \\
\hline & R6, R7, R8, R9 & $\begin{array}{ll}\text { - } & \text { Environmentally sound } \\
\text { - } & \text { CSR }\end{array}$ \\
\hline & & - Legal consequences \\
\hline & R8 & - $\quad$ Roles of housewives \\
\hline & R7 & - A growing trend \\
\hline & R10 & - A variety of activities \\
\hline \multicolumn{3}{|c|}{ Tourists' points of view if marketers have failed or have never really tried to adopt the concept. } \\
\hline \multirow{4}{*}{ Local } & R1, R2, R3, R4, R5 & $\begin{array}{ll}\text { - } & \text { Government's role \& contribution } \\
\text { - } & \text { Advertisements }\end{array}$ \\
\hline & $\mathrm{R} 1, \mathrm{R} 2, \mathrm{R} 3, \mathrm{R} 4$ & $\begin{array}{l}\text { - } \quad \text { Eco-label } \\
\text { - Strategy to reach public }\end{array}$ \\
\hline & R2 & - $\quad$ Remains doubtful \\
\hline & R5 & - $\quad$ Business practice \\
\hline \multirow{3}{*}{ International } & R6, R8, R9, R10 & $\begin{array}{ll}\text { - } & \text { Extensive advertisements } \\
\text { - } & \text { A developed concept } \\
\text { - } & \text { Scepticism }\end{array}$ \\
\hline & R7 & $\begin{array}{l}\text { - Environmental issues in China } \\
\text { - Emerging trend }\end{array}$ \\
\hline & R9 & $\begin{array}{l}\text { - Challenging task to compete with poor ones. } \\
\text { - Government agency }\end{array}$ \\
\hline \multicolumn{3}{|c|}{ Awareness related to green practices by the hotel industry. } \\
\hline \multirow{4}{*}{ Local } & R1, R3 & - $\quad$ Lack of tangibility \\
\hline & $\mathrm{R} 2, \mathrm{R} 3$ & - $\quad$ Not apparent like product-based industry \\
\hline & R4 & $\begin{array}{ll}\text { - } & \text { In-room options } \\
\text { - } & \text { Practiced widely by luxury hotels } \\
\text { - } & \text { Signs \& notifications }\end{array}$ \\
\hline & R5 & $\begin{array}{l}\text { - } \text { Quality service } \\
\text { - } \quad \text { Reduce wastage }\end{array}$ \\
\hline \multirow{4}{*}{ International } & R6, R8, R9 & $\begin{array}{ll}\text { - } & \text { Verdant greenery } \\
\text { - } & \text { Forest \& wildlife }\end{array}$ \\
\hline & R6 & - A way to escape from the heat of plains \\
\hline & R7 & - Energy saving technologies \\
\hline & R10 & - Examples of green strategies \\
\hline
\end{tabular}

\section{Conclusion}

The facts delivered in this study are aimed to achieve several purposes. The first purpose is to comprehend the general understanding of green marketing among local and international tourists. Based on the discussions, the green marketing concept is growing gradually in Malaysia. Even though the respondents were not able to give a comprehensive explanation, they were still able to relate to the overall idea of green marketing and this shows 
that the people are aware about the environmental activities carried out in the country. It is also visible that the Malaysian government has taken holistic approaches to combat the environmental issues in the country. Campaigns and promotions undertaken by the government have influenced the locals progressively towards the preservation of the ecosystem. It is basically undeniable that the government is taking initiatives to transform the existing situation in Malaysia into a better and "greener" one (Rahim, Zukni, Ahmad, \& Lyndon, 2012). For example, as mentioned by one of the respondents regarding "No Plastic Bags on Saturdays", Singh (2011) mentions in his report that the campaign launched by the Domestic Trade, Cooperatives and Consumerism Ministry to minimise the use of plastic bags in the country. Also mentioned, it is one of the ways to preserve the environment and the depleting resources, and it is also a good strategy to infuse environmentally friendly values among the public and businesses. The money collected from the public would be channelled into a special fund which can be used to preserve the environment and to conduct environmental related programmes as well as activities for the local community. This campaign is basically seen as a way to embrace green commitments among consumers and the public (Shrikanth \& Raju, 2012; Yee \& Zailani, 2012).

In return, the concept seems very much established in international markets and this could be due to the role played by developed nations (e.g., United States, Australia \& Singapore) in promoting equitable development and sustainability within the country. The attempts taken by these nations appear to give more fruitful outcomes to produce better tangible results in the struggle to close the gap between the development and the sustainability of the countries. However, developing countries like Malaysia and China are experiencing a recent resurgence as the environmental issues have begun to seize the public's concerns. In conclusion, it is clear that green marketing plays a pioneering role in developed nations such as the United States, Australia and Singapore while it is an emerging concept in developing countries like Malaysia and China.

In response to the second research question, both groups seem to share some similar thoughts. It is believed that many companies have begun to adopt green practices and are making a win-win endeavour for both practitioners and consumers. Despite operating in an environmentally responsible way, it also seems essential for businesses to advertise their green attributes. However, it is apparent that consumers often get confused by the green claims made by companies. Many marketers take advantage of this confusion to exaggerate their claims or make their products or services appear to possess attributes that have no relevance to sustainability. This, to a certain degree, exploits the demand of the green segments. As a way to overcome this problem, many countries have taken some holistic approaches. For example, the U.S. Federal Trade Commission (FTC) has established new standards for truth in "green" advertising to protect the public from false product claims. The green guides are also updated where a list of descriptions for frequently used green product claims are provided (Northen, 2011). The reason is to assist marketers to use the right terminologies in promotion and packaging, and to help the public clearly understand the new terminologies. According to Rashid (2009, p. 132), in Malaysia, "the Standards and Industrial Research Institute of Malaysia (SIRIM) has launched a national eco-labelling program verifying products according to environmental criteria such as Environmentally Degradable, Non-toxic Plastic Packaging Material, Hazardous Metal-Free Electrical and Electronic Equipment, Biodegradable Cleaning Agents and Recycled Paper.” Besides that, in the service sector such as hotels, many nations have developed their own eco-certification schemes (Shieh, 2012). These schemes provide detailed guidance for best sustainable practices and award the eco-friendly label to hotels that meet the requirements.

Concluding the third research question, the locals appeared to have a reasonable awareness about green practices embraced by hoteliers, despite the emphasis on the intangibility nature of services. At the same time, exposure to an international market can also develop one's knowledge and may result in an appreciation and a higher level of awareness on the benefits of sustainable living practices. Additionally, age factor is also predicted to have a substantial impact on the topic studied. It is believed that perceptions of Malaysian consumers towards environmental factors differ by age group and that could possibly be a reason for a lack of interest among baby boomers. Several studies have also stated that consumers' environmental behaviours are influenced by age (Sinnappan \& Rahman, 2011) where the younger generations seem to portray a favourable outcome related to environmental protection or green marketing than the older consumers (e.g., Memery, Megicks, \& Williams, 2005; Ottman, Stafford, \& Hartman, 2006; D’Souza, Taghian, Lamb, \& Peretiatko, 2007; Rahim et al., 2012). Basically, most marketers know that baby boomers and senior citizens are one of the most powerful consumer groups. In fact, beliefs and understandings of this age group of consumers are not similar with other consumer groups. They are users who have practically moved into a new stage of life, bringing in a different mindset. Their needs are more complex and reaching them is not as simple as other groups. In light of this situation, quality remains to be a major consideration for baby boomers. It is believed that choosing or utilising a hotel's services highly depends on the quality of its services and the implementation of green strategies is said to have no effect 
on the overall service quality of a hotel. In the same vein, the care to reduce the amount of waste generated through the use of amenities (e.g., soap bars and bottles) seems obvious even though concern for environmental protection is not shown. However, responses from one respondent shall not be taken to generalise the whole population. Therefore, the evidence obtained in this study can be used as a clue or a direction on how this group of consumers can be further studied, let it be in a hotel context or any others.

On the other hand, international tourists look at the green practices from various perspectives. The natural surroundings, supply chain, renewable energy and life span of durable goods are their familiarities. This pinpoints the extent to how the sustainable preferences among hotels are being understood. This further supports the previous statement about the level of publicity and exposure given to the international citizens regarding green marketing. In relation to this, the green marketing concept should not just be adopted as a marketing tactic, but has to be considered with much greater dynamism, as it has ecological and social elements within it. Based on the research findings, it can be said that the concept has evolved hastily in developed countries while it is an emerging trend in developing countries like Malaysia. While hotels have already started to react to environmental concerns in the country, the lack of promotions and advertisements have become the causes of knowledge non-appearance. Thus, the public needs to be informed and educated about the benefits that green marketing could give to the society and the environment. Moreover, the green practices by hotels need to be made more obvious to the public to gain their full support.

\section{Managerial Implications}

For environmental protection to become a reality, it is important for all stakeholders to take part. On this point of view, the government has equal responsibilities as those practitioners in the industry. At present, there are many environmental awareness initiatives initiated by the government around the country which focus on various parts of the environment. This situation also applies to governments in international markets. Governments are seen to have all the abilities to create awareness and they are expected to fulfill the responsibilities of educating the public on conserving the environment. At this point, governments should strive to update and prepare strategies to integrate environment and development at all levels. Due respect should be given to the demonstration of huge differences that each individual can make to the environment by making small changes to their lifestyles. This should be done in collaboration and cooperation with all sectors of the society. One way to approach this would be through media reports as the media has a definite role in creating awareness and educating the public appropriately compared to other methods. While awareness about activities related to environmental protection is not obvious, the hoteliers may strengthen the benefits of green practices in their promotional activities to induce green purchasing and consumption behaviour. A thorough review on customer-defined needs should be undertaken by hotel managers in the process of incorporating green practices into their hotels' daily operations without any deterioration of service quality. The review must be able to create a win-win situation for both hoteliers and customers in which green practices must be able to reduce the overall operational costs without affecting the customers' satisfaction level.

\section{Limitations and Future Research}

Even though the method selected for this study includes limitations to interpretations and generalization of results to larger populations (Marshall \& Rossman, 1999; Patton, 2002), yet it still offers some insights on how the evidence can be further studied in the process of establishing a genuine relationship between hoteliers and their customers. The baby boomer who is conscious about his needs and quality in the products and services that he buys demonstrates a platform for future studies. In addition, examination of the impact of various age groups towards hotels' green consumption would be a meaningful extension of this study. It also appears in the findings that green marketing has continually gained adherents in the course of growing market for environmentally friendly products and services. In the hotel settings, consumers (including local and international tourists) are aware about the green practices incorporated within the service delivery process. However, there is a need to know if this awareness could lead towards green purchasing intention and real purchasing behaviour. At this point, this research assumes that there must be various determinants of purchasing intention and behaviour. As the government is seen as an important stakeholder who is responsible in promoting and creating awareness about environmental protection, the role played by the government can be one of the determinants and shall be integrated into a study of such aforementioned relationships. While this study sought to understand to what extent tourists are aware about the green practices embraced by hoteliers, it may also be interesting to see how tourists respond to the hotels' various green marketing strategies. This certainly provides some guidelines to the practitioners to organise their strategies effectively. 


\section{References}

Adams, A., \& Cox, A. L. (2008). Questionnaires, in-depth interviews and focus groups. In P. Cairns, \& A. L. Cox (Eds.), Research Methods for Human Computer Interaction (pp. 17-34). Cambridge, UK: Cambridge University Press.

Aman, A. H. L., Harun, A., \& Hussein, Z. (2012). The influence of environmental knowledge and concern on green purchase intention: The role of attitude as a mediating variable. British Journal of Arts and Social Sciences, 7(2), 145-167.

Ary, D., Jacobs, L. C., Razavieh, A., \& Sorensen, C. (2009). Introduction to research in education. Wadsworth Publishing Company.

Baum, L. M. (2012). It's not easy being green... Or is it? A content analysis of environmental claims in magazine advertisements from the United States and United Kingdom. Environmental Communication: A Journal of Nature and Culture, 6(4), 423-440. http://dx.doi.org/10.1080/17524032.2012.724022

Berry, L. L. (1980). Services marketing is different. Business, 30(3), 24-29.

Bhaskaran, S., Polonsky, M., Cary, J., \& Fernandez, S. (2006). Environmentally sustainable food production and marketing: Opportunity or hype? British Food Journal, 108(8), 677-690. http://dx.doi.org/10.1108/0007070 0610682355

Bursa Malaysia Berhad. (2010). Hotels. Retrieved from http://ablemen.com/sustainability/lock/focus_hotels. php?index $=9$

Chamorro, A., \& Bañegil, T. M. (2006). Green marketing philosophy: A study of Spanish firms with ecolabels. Corporate Social Responsibility and Environmental Management, 13(1), 11-24. http://dx.doi.org/10.1002/ csr.83

Chamorro, A., Rubio, S., \& Miranda, F. J. (2009). Characteristics of research on green marketing. Business Strategy and the Environment, 18(4), 223-239. http://dx.doi.org/10.1002/bse.571

Chan, E. S. (2008). Barriers to EMS in the hotel industry. International Journal of Hospitality Management, 27(2), 187-196. http://dx.doi.org/10.1016/j.ijhm.2007.07.011

Charter, M. (1992). Greener marketing - A responsible approach to business. Sheffield: Greenleaf.

Charter, M., \& Polonsky, M. J. (1999). Greener marketing: A global perspective on greening marketing practice (2nd ed.). Sheffield: Greenleaf.

Chen, Y. S. (2010). The drivers of green brand equity: Green brand image, green satisfaction, and green trust. Journal of Business Ethics, 93(2), 307-319. http://dx.doi.org/10.1007/s10551-009-0223-9

Chen, Y. S., \& Chang, C. H. (2012). Enhance green purchase intentions: The roles of green perceived value, green perceived risk, and green trust. Management Decision, 50(3), 502-520. http://dx.doi.org/10.1108/ 00251741211216250

Coddington, W. (1992). Environmental marketing. New York: McGraw-Hill.

Coddington, W. (1993). Environmental marketing: Positive strategies for reaching the green consumer. New York: McGraw-Hill.

Creswell, J. W. (2012). Qualitative inquiry and research design: Choosing among five approaches. SAGE Publications, Incorporated.

D’Souza, C., Taghian, M., Lamb, P., \& Peretiatko, R. (2007). Green decisions: Demographics and consumer understanding of environmental labels. International Journal of Consumer Studies, 31(4), 371-376. http://dx.doi.org/10.1111/j.1470-6431.2006.00567.x

Fernández-Alles, M., \& Cuadrado-Marqués, R. (2012). Hotel environmental impact management: A case study in Cádiz Province. Soft Computing in Management and Business Economics, 335-346. http://dx.doi.org/10. 1007/978-3-642-30451-4_23

Fisk, G. (1974). Marketing and the ecological crisis. New York: Harper \& Row.

Fraenkel, J. R., \& Wallen, N. E. (2003). How to design and evaluate research in education (5th ed.). Boston: McGraw Hill.

Fuller, D. A. (1999). Sustainable marketing: Managerial-ecological issues (Vol. 407). Thousand Oaks: Sage Publications. 
Ginsberg, J. M., \& Bloom, P. N. (2004). Choosing the right green marketing strategy. MIT Sloan Management Review, 46(1), 79-84.

Green Hotels Association. (n. d.). Certification. Retrived from http://www.greenhotels.com/

Ham, S., \& Choi, Y. K. (2012). Effect of cause-related marketing for green practices in the hotel industry. Journal of Global Scholars of Marketing Science, 22(3), 249-259. http://dx.doi.org/10.1080/21639159. 2012.696338

Han, H., Hsu, L. T. J., \& Lee, J. S. (2009). Empirical investigation of the roles of attitudes toward green behaviors, overall image, gender, and age in hotel customers' eco-friendly decision-making process. International Journal of Hospitality Management, 28(4), 519-528. http://dx.doi.org/10.1016/j.ijhm.2009.02. 004

Hartmann, P., Ibanez, V. A., \& Sainz, F. J. F. (2005). Green branding effects on attitude: Functional versus emotional positioning strategies. Marketing Intelligence \& Planning, 23(1), 9-29. http://dx.doi.org/10.1108/ 02634500510577447

Henion, K. E., \& Kinnear, T. C. (1976). Ecological marketing: American Marketing Association's (AMA's) first national workshop on ecological marketing. Chicago, IL: AMA.

Jay, M. (1995). Environmental marketing: Strategies, practice, theory, and research. Psychology Press.

KeTTHA. (2011). Going green: Morally sustainable \& financially viable. Retrieved from http://www.kettha.gov.my/en/content/going-green-morally-sustainable-financially-viable

KPMG Green Tax Index, (2013, April 23). An exploration of green tax incentives and penalties. Retrived from http://www.kpmg.com/Global/en/IssuesAndInsights/ArticlesPublications/green-tax/Documents/kpmg-green -tax-index-2013.pdf

Leonidou, C. N., \& Leonidou, L. C. (2011). Research into environmental marketing/management: A bibliographic analysis. European Journal of Marketing, 45(1/2), 68-103. http://dx.doi.org/10.1108/0309056 1111095603

Leonidou, C. N., Katsikeas, C. S., \& Morgan, N. A. (2013). “Greening” the marketing mix: Do firms do it and does it pay off? Journal of the Academy of Marketing Science, 41(2), 151-170. http://dx.doi.org/10.1007/ s11747-012-0317-2

List, D. (2004). Maximum variation sampling for surveys and consensus groups, Adelaide: Audience Dialogue. Retrieved from http://www.audiencedialogue.org/maxvar.html

Malay Mail Online. (2014, January 19). 10 hotels in Malaysia win Asean Green Hotel title. Retrived from http://www.themalaymailonline.com/travel/article/ten-hotels-in-malaysia-win-asean-green-hotel-title

Marshall, B., Cardon, P., Poddar, A., \& Fontenot, R. (2013). Does sample size matter in qualitative research?: A review of qualitative interviews in IS research. Journal of Computer Information Systems, 54(1), 11-22.

Marshall, C., \& Rossman, G. B. (1999). Designing qualitative research (3rd ed.). Thousand Oaks, CA: Sage Publications.

Marshall, M. N. (1996). Sampling for qualitative research. Family Practice, 13(6), 522-526. http://dx.doi.org/10.1093/fampra/13.6.522

Memery, J., Megicks, P., \& Williams, J. (2005). Ethical and social responsibility issues in grocery shopping: A preliminary typology. Qualitative Market Research: An International Journal, 8(4), 399-412. http://dx.doi.org/10.1108/13522750510619760

Menon, A., \& Menon, A. (1997). Enviropreneurial marketing strategy: The emergence of corporate environmentalism as market strategy. The Journal of Marketing, 61, 51-67. http://dx.doi.org/10.2307/ 1252189

Mensah, I. (2004). Environmental management practices in US hotels. Retrieved from: http://www.hotelonline.com/News/PR20042nd/May04EnvironmentalPractices.html

Ministry of Tourism and Creative Economy. (2012, January 11). Asean Green Hotel Recognition Award 2012. Retrieved from http://www.scribd.com/doc/83861400/ASEAN-Green-Hotel-Recognition-Award-2012

Mitchell, M. L., \& Jolley, J. M. (2004). Research design explained. Belmont: Warsworth.

Myung, E., McClaren, A., \& Li, L. (2012). Environmentally related research in scholarly hospitality journals: 
Current status and future opportunities. International Journal of Hospitality Management, 31(4), 1264-1275. http://dx.doi.org/10.1016/j.ijhm.2012.03.006

Neuman, W. L., \& Kreuger, L. (2003). Social work research methods: Qualitative and quantitative approaches. Allyn and Bacon.

Northen, G. (2011). Greenwashing the organic label: Abusive green marketing in an increasingly eco-friendly marketplace. J. Food L. \& Pol'y, 7, 101.

Omran, A., Mahmood, A., Aziz, H. A., \& Robinson, G. M. (2009). Investigating households attitude toward recycling of solid waste in Malaysia: A case study. International Journal of Environmental Research, 3(2), 275-288.

Ottman, J. A. (1993). Green marketing: Challenges and opportunities for the new marketing age. Lincolnwood, IL: NTC.

Ottman, J. A., Stafford, E. R., \& Hartman, C. L. (2006). Avoiding green marketing myopia: Ways to improve consumer appeal for environmentally preferable products. Environment, 48(5), 22-36. http://dx.doi.org/10.3200/ENVT.48.5.22-36

Patton, M. Q. (2002). Qualitative research \& evaluation methods (3rd ed.). Thousand Oaks, CA: Sage Publications.

Peattie, K. (1995). Environmental marketing management. London: Pitman.

Peattie, K. (2001). Towards sustainability: The third age of green marketing. The Marketing Review, 2(2), 129-146. http://dx.doi.org/10.1362/1469347012569869

Pizam, A. (2009). Green hotels: A fad, ploy or fact of life? International Journal of Hospitality Management, 28(1), 1. http://dx.doi.org/10.1016/j.jijm.2008.09.001

Polonsky, M. J. (1994). Green Marketing Regulation in the US and Australia: The Australian Checklist. Greener Management International, 5, 44-53.

Pride, W. M., \& Ferrell, O. C. (1993). Marketing (8th ed.). Boston, MA: Houghton Mifflin.

Punitha, S., \& Rasdi, R. M. (2013). Corporate social responsibility: Adoption of green marketing by hotel industry. Asian Social Science, 9(17), 79-93. http://dx.doi.org/10.5539/ass.v9n17p79

Rahim, M. H. A., Zukni, R. Z. J. A., Ahmad, F., \& Lyndon, N. (2012). Green advertising and environmentally responsible consumer behavior: The level of awareness and perception of Malaysian youth. Asian Social Science, 8(5), 46-54. http://dx.doi.org/10.5539/ass.v8n5p46

Rahman, I., Reynolds, D., \& Svaren, S. (2011). How "green” are North American hotels? An exploration of low-cost adoption practices. International Journal of Hospitality Management, 31(3), 720-727. http://dx.doi.org/10.1016/j.ijhm.2011.09.008

Rashid, N. R. N. A. (2009). Awareness of eco-label in Malaysia's green marketing initiative. International Journal of Business and Management, 4(8), 132-141. http://dx.doi.org/10.5539/ijbm.v4n8p132

Richards, L., \& Morse, J. M. (2012). Readme first for a user's guide to qualitative methods. Sage Publications, Incorporated.

Russell, C. K., \& Gregory, D. M. (2003). Evaluation of qualitative research studies. Evidence Based Nursing, 6(2), 36-40. http://dx.doi.org/10.1136/ebn.6.2.36

Sandelowski, M. (1995). Sample size in qualitative research. Research in Nursing \& Health, 18(2), 179-183. http://dx.doi.org/10.1002/nur.4770180211

Shafaat, M. F., \& Sultan, A. (2012). Green marketing. EXCEL International Journal of Multidisciplinary Management Studies, 2(5), 184-195.

Shieh, H. S. (2012). The greener, the more cost efficient? An empirical study of international tourist hotels in Taiwan. International Journal of Sustainable Development \& World Ecology, 19(6), 536-545. http://dx.doi.org/10.1080/13504509.2012.741627

Shrikanth, R., \& Raju, D. S. N. (2012). Contemporary green marketing - Brief reference to Indian scenario. International Journal of Social Sciences \& Interdisciplinary Research, 1(1), 26-40.

Singh, D. (2011, January 1). No plastic bags on Saturdays. The Star Online. Retrieved from http://thestar.com.my/news/story.asp?file=/2011/1/1/nation/2011010154253\&sec=nation 
Sinnappan, P., \& Rahman, A. A. (2011). Antecedents of green purchasing behavior among Malaysian consumers. International Business Management, 5(3), 129-139. http://dx.doi.org/10.1080/13504509.2012.741627

Smith, T. (1998). The myth of green marketing: Tending our goats at the edge of apocalypse. Toronto: University of Toronto Press.

Soonthonsmai, V. (2007). Environmental or green marketing as global competitive edge: Concept, synthesis, and implication. In EABR (Business) and ETLC (Teaching) Conference Proceeding, Venice, Italy.

The News. (2011, May 19). Malaysia unveils plan to build 'green economy'. Retrived from http://www.thenews. com.pk/Todays-News-3-47703-Malaysia-unveils-plan-to-build-\%E2\%80\%98green-economy\%E2\%80\%99

van Dam, Y. K., \& Apeldoorn, P. A. (1996). Sustainable marketing. Journal of Macromarketing, 16(2), 45-56. http://dx.doi.org/10.1177/027614679601600204

Veno, J. (2014). 10 hotels from M'sia receive Asean Green Hotel Award. The Borneo Post. Retrived from http://www.theborneopost.com/2014/01/20/10-hotels-from-msia-receive-asean-green-hotel-award/\#ixzz3flt $6 \mathrm{aV} 2 \mathrm{I}$

World Commission on Environmental Development (1978, December 11). General Assembly. Retrived from http://www.un.org/documents/ga/res/42/ares42-187.htm

World Luxury Tourism, (2014, January 20). ASEAN Green Hotel Award 2014 Presented. Retrived from http://www.worldluxurytourism.com/news/asean-green-hotel-award-2014-presented.html

Yee, L. K., \& Zailani, S. (2012). Determinants of the green quality practices towards sustainable quality management. International Journal of Productivity and Quality Management, 9(2), 194-216. http://dx.doi.org/10.1504/IJPQM.2012.045192

Zeithaml, V. A., Parasuraman, A., \& Berry, L. L. (1985). Problems and strategies in services marketing. The Journal of Marketing, 49(2), 33-46. http://dx.doi.org/10.2307/1251563

\section{Appendix}

\section{List of interview questions}

1. What is green marketing?

2. What are some examples of green marketing that you know of?

3. Who is responsible in implementing the concept?

4. To what extent do you think the marketers of public or private organisations have adopted the concept?

5. How much have hotels included the green marketing concept into their daily operations or service delivery?

6. What are some examples that you know of?

Note. Additional questions were asked as follow up to any interesting or unexpected answers given by the respondents.

\section{Copyrights}

Copyright for this article is retained by the author(s), with first publication rights granted to the journal.

This is an open-access article distributed under the terms and conditions of the Creative Commons Attribution license (http://creativecommons.org/licenses/by/3.0/). 